\title{
Changes of Riverbeds and Water-carrying Capacity of the Yellow River Inner Mongolia Section
}

\author{
Zhenquan $\mathrm{Li}^{1,2, *}$, Qiaoyu $\mathrm{Li}^{3}$, Zihao Chen ${ }^{2}$, Yimin $\mathrm{Wang}^{1}$ \\ ${ }^{1}$ School of Water Resources and Hydropower, Xi'an University of Technology, Xi'an 710048, China \\ ${ }^{2}$ Huangzangsi Project Construction \& Management Bureau, HRB, Lanzhou 730030, China \\ ${ }^{3}$ Henan Vocational College of Water Conservancy and Environment, Zhengzhou 462000, China
}

\begin{abstract}
This paper introduced the evolution of the section from Bayangaole to Toudaoguai in the Yellow River and analysed the factors influencing erosion, deposition, and water-carrying capacity of the section over years. Through data obtained from observation in the Bayangaole station, Sanhuhekou station, Zhaojunfen station, and Toudaoguai station, after analysis, it has been got that the riverbeds observed at these stations have been silted up over time, and the water-carrying capacity has been reducing. Besides, the construction of reservoirs or power stations may accelerate this trend.
\end{abstract}

\section{Background}

With the joint operation of Longyangxia Power Station and Liujiaxia Reservoir, the natural surface flow course of the Yellow River changed (Su et al., 2015); especially since 1991, the amount of water from upstream of the Yellow River has been withering to an average surface flow of less than 20 billion cubic meters per year and a minimum flow of about 10 billion cubic meters per year (Liu et al., 2009). With the continuous decreasing of water from the upstream, the main riverbeds shrink year by year, and are clogged with silt. As is recorded, compared with that in 1981, Bayangaole section silts up about 4m, Sanhuhekou section silts up about $3 \mathrm{~m}$, Zhaojunfen section silts up about $2.6 \mathrm{~m}$, and Toudaoguai section silts up about $1 \mathrm{~m}$. Since stream bed silted up year by year, some sections have become above ground river, which already begun to overflow under the flow of 1500 cubic meters per second. Besides, water-carrying capacity reduces greatly, for instance, the watercarrying capacity of Bayangaole and Sanhuhekou sections are less than 30\% of that in 1981 (Shen et al.,2013); and the freezing period are much longer than the standard period of time, while the distance from water surface to dyke is less than $2 \mathrm{~m}$. Therefore, the prediction of drift period and flood period, and the according schemes for ice prevention, flood control and forecast should be changed with the situation (Hou et al., 2010).

\footnotetext{
* Corresponding author : 1zq1816@163.com
} 


\section{Introduction of the Inner Mongolia section in the yellow river}

The Inner Mongolia section in the Yellow River is $830 \mathrm{~km}$ long, of which the section studied in this paper is $521 \mathrm{~km}$ long from Bayangaole to Toudaoguai, which is a wandering section clustered with ditches and bunchy streams.

\section{Trend of erosion or deposition in each section}

To know the erosion or deposition trend in each section, data through observation of four hydrological stations from Bayangaole to Toudaoduai are applied, which are Bayangaole Hydrological Station, Sanhuhekou Hydrological Station, Zhaojunfen Hydrological Station and Toudaoguai Hydrological Station ( $\mathrm{Li}$ et al., 2009). Please refer to the following four figures for variation tendency of the erosion and deposition observed from these four stations (Figure 1, 2, 3 and 4). As is shown, the curve of 1981 is set as the baseline (bold line) which broadly divides the whole period into two phases: before 1981, the riverbed was generally in the trend of erosion; after that, decomposition took the trend (Tang et al., 2015).

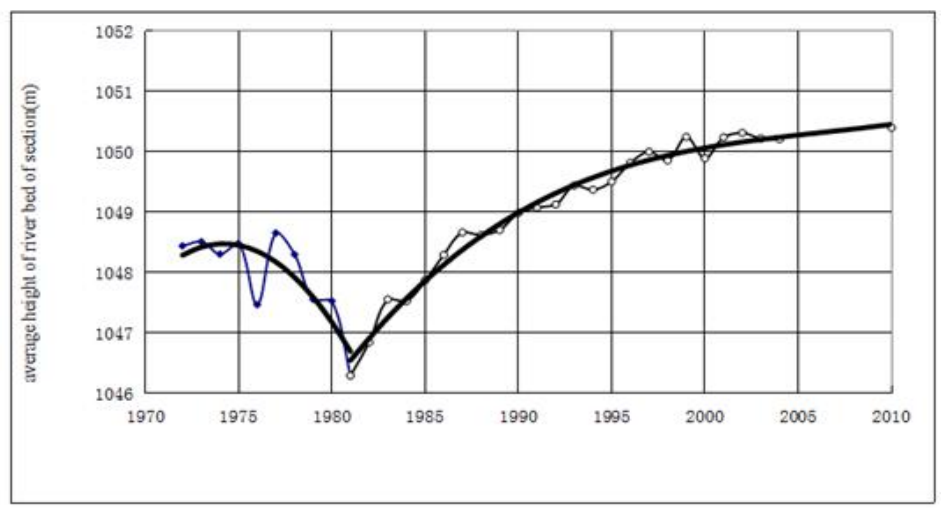

Fig. 1. Variable state of erosion and deposition to river bed of Bayangaole section in calendar year

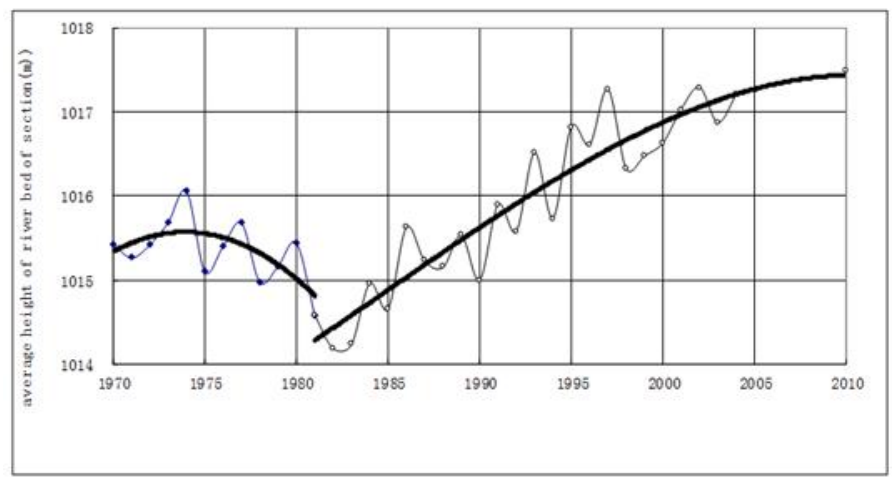

Fig. 2. Variable state of erosion and deposition to river bed of Sanhuhekou section in calendar year 


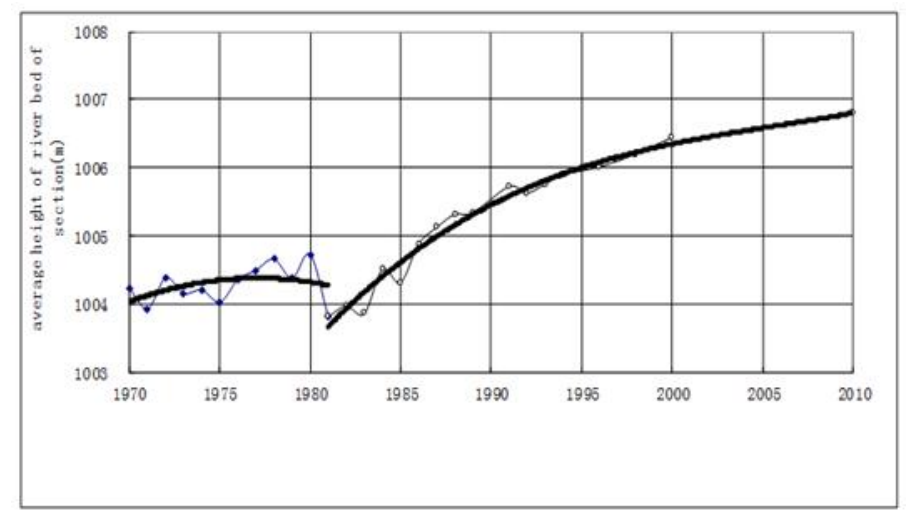

Fig. 3. Variable state of erosion and deposition to river bed of Zhaojunfen section in calendar year

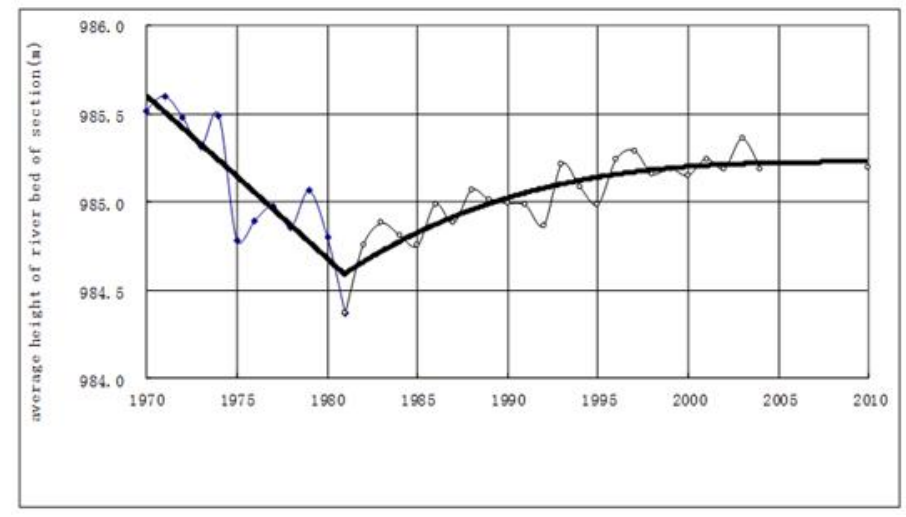

Fig. 4. Variable state of erosion and deposition to river bed of Toudaoguai section in calendar year

\section{FACTORS AFFECTING EROSION AND DEPOSITION}

\subsection{Influence of flood at various water discharge rate}

Following are erosion or deposition of riverbeds in Bayangaole, Sanhuhekou, Zhaojunfen, and Toudaoguai sections under a peak water discharge rate of $2000 \mathrm{~m}^{3} / \mathrm{s}, 2000 \mathrm{~m}^{3} / \mathrm{s} \sim 3000$ $\mathrm{m}^{3} / \mathrm{s}, 3000 \mathrm{~m}^{3} / \mathrm{s}-4000 \mathrm{~m}^{3} / \mathrm{s}$, and over $4000 \mathrm{~m}^{3} / \mathrm{s}$ respectively based on historical data (Chang et al., 2009). It is found that:

(1) When the peak water discharge rate is less than $2000 \mathrm{~m}^{3} / \mathrm{s}$, in high water level stage, the riverbeds in Sanhuhekou and Zhaojunfen sections erode, while those in Bayangaole and Toudaoguai sections silt up; however, the situation in low water level stage is just the opposite. Generally speaking, the riverbed in these four sections does not change significantly at such a water discharge rate (Hou et al., 2007).

(2) When the peak water discharge rate is $2000 \mathrm{~m}^{3} / \mathrm{s} \sim 3000 \mathrm{~m}^{3} / \mathrm{s}$, the riverbeds of Sanhuhekou, Zhaojunfen and Toudaoguai sections erode in high water level stage and silt up in low water level stage. It is found that during a flood, riverbed of Bayangaole section erodes, but begins to silt up afterward. In other sections, either serious erosion or severe deposition occurs after such a flood.

(3) When the peak water discharge rate is over $3000 \mathrm{~m}^{3} / \mathrm{s}$, riverbeds in all sections are seriously eroded first and then silt up severely after a flood. For example, in 1979, the 
average eroded height of riverbeds in Bayangaole, Sanhuhekou, Zhaojunfen, and Toudaoguai sections were $2.90 \mathrm{~m}, 3.48 \mathrm{~m}, 3.16 \mathrm{~m}$, and $0.27 \mathrm{~m}$ respectively; while the silting up height were $2.41 \mathrm{~m}, 3.27 \mathrm{~m}, 2.74 \mathrm{~m}$, and $0.81 \mathrm{~m}$ respectively after the flood. After calculation, it is figured out that the riverbeds of Bayangaole, Sanhuhekou, and Zhaojunfen sections were eroded by $0.49 \mathrm{~m}, 0.21 \mathrm{~m}$, and $0.42 \mathrm{~m}$ respectively, while that of Toudaoguai section silted up by $0.54 \mathrm{~m}$. However, in 1981, the riverbeds of these four sections were eroded by $4.08 \mathrm{~m}, 4.76 \mathrm{~m}, 4.66 \mathrm{~m}$, and $1.27 \mathrm{~m}$ respectively during flood, and were silted up by $2.37 \mathrm{~m}, 3.45 \mathrm{~m}, 3.65 \mathrm{~m}$, and $1.07 \mathrm{~m}$ respectively. Therefore, in general, the riverbeds of these four sections were eroded by $1.71 \mathrm{~m}, 1.31 \mathrm{~m}, 1.01 \mathrm{~m}$, and $0.20 \mathrm{~m}$ respectively.

(4) When the flood is fluctuated with a peak flow of over $3000 \mathrm{~m}^{3} / \mathrm{s}$, it is observed that erosion in Bayangaole section appears to be obvious during the first flood peak, and slow in later peaks. However, riverbeds in Sanhuhekou, Zhaojunfen and Toudaoguai sections were eroded when the water level was rising and silted up while the flood was over.

(5) Based on the erosion and deposition situation of every section, preliminary results on every section at all flood levels can be drawn in an illustration, which shows that: the erosion and deposition of riverbed are obviously remarkable when the peak water discharge rate and the average daily water discharge rate are over $3000 \mathrm{~m}^{3} / \mathrm{s}$ and over $2000 \mathrm{~m}^{3} / \mathrm{s}$ respectively for 40 days. When the water discharge rate is less than $3000 \mathrm{~m}^{3} / \mathrm{s}$, though the riverbeds might be eroded during the flood, they will silt up afterwards. As a result, the riverbed will not be substantially eroded (Wang et al., 2010).

\subsection{Influence of various flood volume}

It has been figured out that the influence of flood volume on erosion or deposition of Sanhuhekou section is similar, while the influence of flood volume on Toudaoguai section is less (see Figure 5). The quantitative relationship between erosion or deposition variance of riverbed and the flood volume in Bayangaole and Sanhuhekou sections is: $y=$ $0.0000614 \times x 2+0.020755 \times x$, with a correlation coefficient of 0.95 ; while the quantitative relationship between them in Toudaoguai section is: $y=-0.0000324 \times \mathrm{x} 2+0.010195 \times \mathrm{x}$, with a correlation coefficient of 0.97 ; Where, $y$ refers to the erosion or deposition variance (unit: $\mathrm{m}$ ), and $\mathrm{x}$ means flood volume (unit: hundred million $\mathrm{m}^{3}$ )

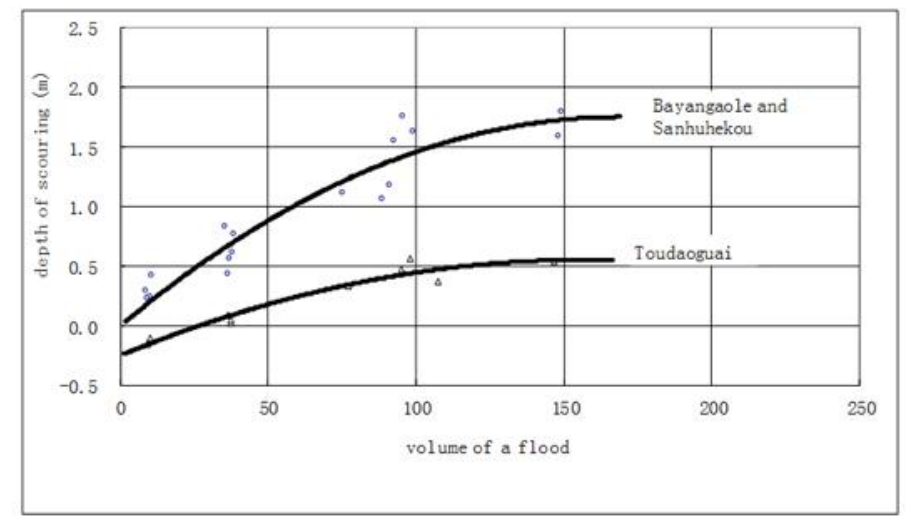

Fig. 5. The quantitative relationship of the variance of erosion and deposition on river bed under a flood volume of each section

\subsection{Influence of annual runoff volume}

It is analysed that there is a linear relation between the annual runoff and erosion or deposition variance in Bayangaole, Sanhuhekou, Zhaojunfen, and Toudaoguai sections. 
Please refer Figure 6 for the linear relation of them in Bayangaole section (Figure 6). Besides, the quantitative relations in Bayangaole, Sanhuhekou, Zhaojunfen, and Toudaoguai sections are: $y=-0.01221 \times x+2.366$, with a correlation coefficient of 0.79 ; $y$ $=-0.00906 \times x+1.843$, with a correlation coefficient of $0.74 ; y=-0.00770 \times x+1.681$, with a correlation coefficient of 0.68 ; and $y=-0.00201 \times x+0.396$, with a correlation coefficient of 0.54 ; Where $y$ refers to the erosion or deposition variance (unit: $\mathrm{m}$ ), and $\mathrm{x}$ means the annual runoff (unit: hundred million $\mathrm{m}^{3}$ ).

After quantitative analysis with above formulae, it is found that there is a strong relation between the annual runoff and erosion or deposition variance. It is figured out that for every 100 million $\mathrm{m}^{3}$ of annual runoff, the erosion or deposition variance in riverbeds of Bayangaole section, Sanhuhekou section, Zhaojunfen section, and Toudaoguai section is $0.0122 \mathrm{~m}, 0.0091 \mathrm{~m}, 0.0077 \mathrm{~m}$, and $0.0020 \mathrm{~m}$ respectively. Besides, it is shown that the influence of runoff on erosion or deposition of riverbed Bayangaole section is reduced gradually with the extension of the river reach ( $\mathrm{Su}$ et al., 2015).

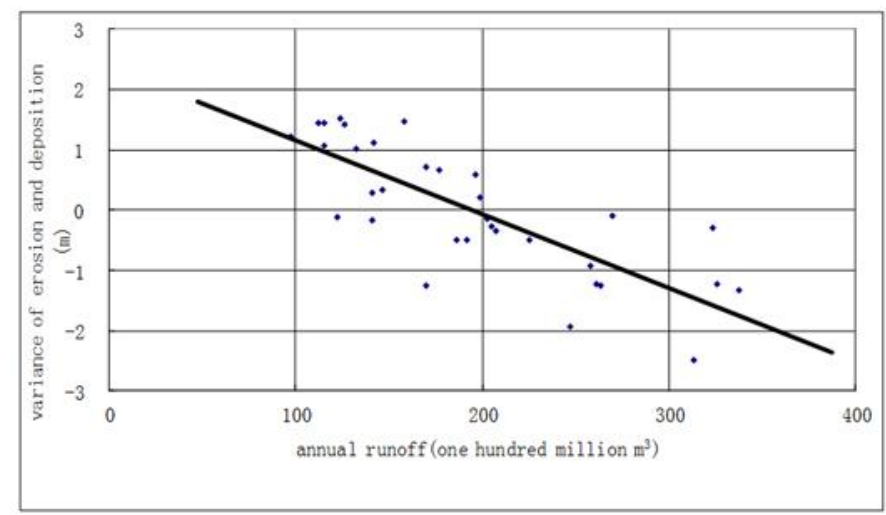

Fig. 6. Relationship of annual runoff and variance of erosion and deposition of Bayangaole

\subsection{Influence of flow regime on different riverbeds}

Since the riverbed of Inner Mongolia section in the Yellow River is made of flour sand, it is extremely apt to change. According to analysis, when the peak water discharge rate exceeds $1350 \mathrm{~m}^{3} / \mathrm{s}$ and the annual runoff volume in a flood reaches 900 million $\mathrm{m}^{3}$, the riverbeds of Bayangaole and Sanhuhekou sections begin to be eroded. However, only when the peak water discharge rate exceeds $2000 \mathrm{~m}^{3} / \mathrm{s}$ and the annual runoff volume under a flood reaches 350 million $\mathrm{m}^{3}$, will riverbed of Toudaoguai section be eroded. For example, in 1981 when the peak water discharge rate observed by each station was $1500 \mathrm{~m}^{3} / \mathrm{s}$, the height of riverbed after flood was basically the same with that before the flood.

As is discussed above, when the peak water discharge rate is over $3000 \mathrm{~m}^{3} / \mathrm{s}$, and the days with a discharge rate of over $2000 \mathrm{~m}^{3} / \mathrm{s}$ last no less than 40 days, the riverbed will be substantially eroded (Wu et al., 2015).

\subsection{Annual runoff volume to maintain a balance between erosion and deposition}

From the analysis of the four sections in the Yellow River, it is found that the runoff volume to maintain a balance between erosion and deposition is different for different sections and is different for one section in different periods of time. Take Bayangaole section for example; from 1982 to1990, when the annual runoff volume was generally over 
15 billion $\mathrm{m}^{3}$ per year, it had a very high deposition speed of riverbed; while from 1991 to 2004, when the annual runoff volume was under 15 billion $\mathrm{m}^{3}$ per year in general, the deposition was slowed down. Another example is Toudaoguai section, when the annual runoff volume is less than 15 billion $\mathrm{m}^{3}$ per year in recent years, the riverbed remains stable; however, from 1982 to1986, when the annual runoff volume exceeded 20 billion $\mathrm{m}^{3}$, the riverbed was depositing in general (Wu et al., 2015).

\section{Estimation on erosion or deposition trend}

According to the above analysis, and based on the premise that the annual runoff volume from 2005 to 2010 was maintained the same with that from 1990 to 2004, with an annual runoff volume of less than 20 billion $\mathrm{m}^{3}$, the erosion or deposition of riverbed in each section was as follows

(1) Bayangaole section: according to the depositing trend from 1982 to 2004 described in Figure 3.1, the average water stage in this section was estimated to reach $1050.50 \mathrm{~m}$ by 2010 , silting up by $0.29 \mathrm{~m}$ as compared with that in 2004 .

(2) Sanhuhekou section: according to the depositing trend from 1983 to 2004 in Figure 3.2, the average water stage in this section was estimated to reach $1017.44 \mathrm{~m}$ by 2010 , silting-up by about $0.23 \mathrm{~m}$ as compared with that in 2004 .

(3) Zhaojunfen section: according to the depositing trend from 1983 to 2000 in Figure 3.3, the average water stage in this section was estimated to reach $1006.80 \mathrm{~m}$ by 2010 , silting-up by about $0.37 \mathrm{~m}$ as compared with that in 2000 .

(4) Toudaoguai section: according to the depositing trend from 1982 to 2004 in Figure 3.4, the average water stage of section in this section was estimated to reach $985.23 \mathrm{~m}$ by 2010 , silting up by about $0.04 \mathrm{~m}$ as compared with that in 2004 .

It is necessary to point out that of the section from Bayangaole to Toudaoguai, silt is mainly piled up from Bayangaole to Zhaojunfen at present. If heavier flood takes place in future, the silt may pass to the lower reaches, therefore, the riverbed of Toudaoguai section may be confronting serious silting up challenge (Yang et al., 2003).

\section{Variation of flow shape and cross section area with time}

(1) Bayangaole section

As is shown in Figure 7, the flow shape and cross section area of Bayangaole section change over time. It is found that the river has been constantly silted up; therefore, the flow area has been reduced and the riverbed has risen in height. Based on a water stage of $1052.5 \mathrm{~m}$, the variation of cross section rate in different periods since 1981 is shown in Table 1 .

(2) Sanhuhekou section

As is shown in Figure 8, the flow shape and cross section area of Sanhuhekou section change over time. It is found that the river has been constantly silted up; therefore, the riverbed is increasing in height, and the cross section area has been reduced. Besides, it is found out that the shape in 1981 is more regular. However, with silt piled up over years, the main trough changed position from side to side. By 2003, the trough had been in the middle section basically, and the shape turned out to be more regular too. Based on a water stage of $1019.7 \mathrm{~m}$, the variation of cross section area in different periods since 1981 is shown in Table 2. 
Table 1. The situation of reduction for the area of different periods of Bayangaole

\begin{tabular}{|c|c|c|c|c|}
\hline \multirow{2}{*}{ years } & \multirow{2}{*}{$\begin{array}{c}\text { Area of section } \\
\left(\mathrm{m}^{2}\right)\end{array}$} & \multicolumn{2}{|c|}{ Reduction of area compared with1981 } & \multirow{2}{*}{$\begin{array}{c}\begin{array}{c}\text { Percentage of the area } \\
\text { of } 1981(\%)\end{array} \\
\end{array}$} \\
\hline & & Absolute value $\left(\mathrm{m}^{2}\right)$ & Relative value (\%) & \\
\hline 1981 & 3299 & & & \\
\hline 1985 & 2887 & -412 & -12.5 & 87.5 \\
\hline 1987 & 1833 & -1466 & -44.4 & 55.6 \\
\hline 1992 & 1576 & -1723 & -52.2 & 47.8 \\
\hline 1997 & 1207 & -2092 & -63.4 & 36.6 \\
\hline 2003 & 1171 & -2128 & -64.5 & 35.5 \\
\hline
\end{tabular}

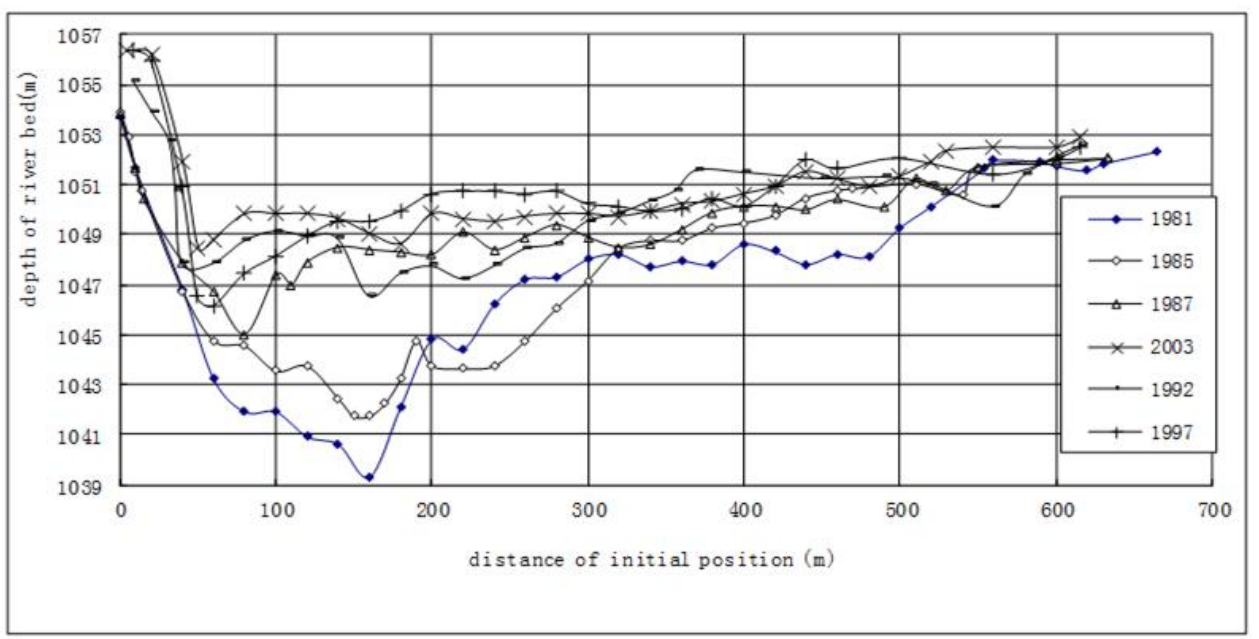

Fig. 7. Graph of cross section of Bayangaole in past years

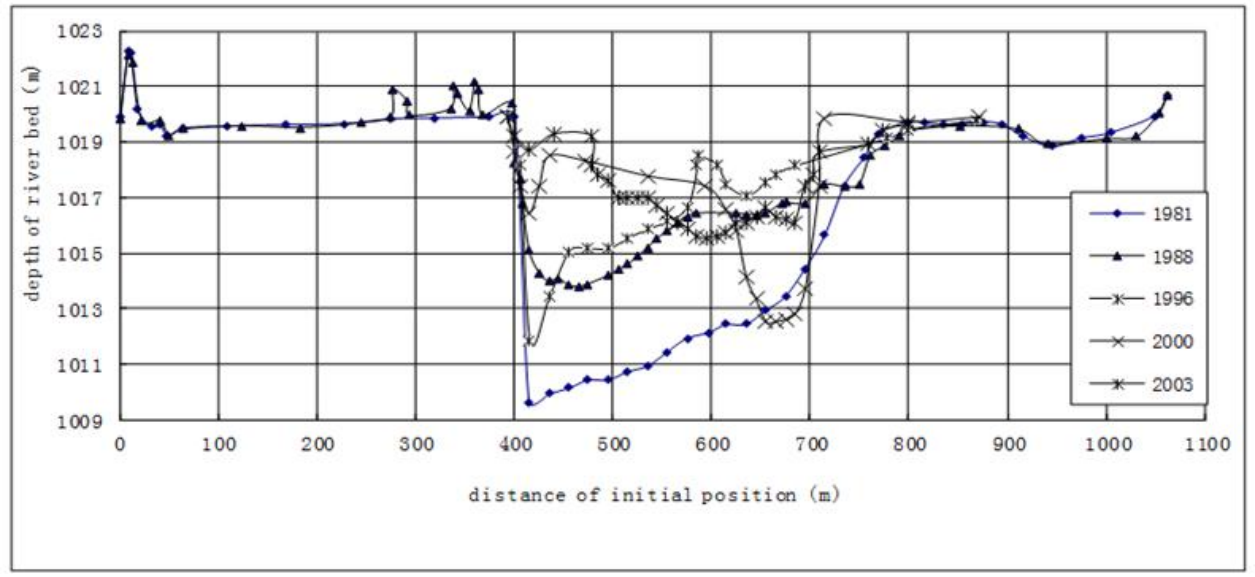

Fig.8. Graph of cross section of Sanhuhekou in past years 
Table 2. The situation of reduction for the area of different periods of Sanhuhekou

\begin{tabular}{|c|c|c|c|c|}
\hline \multirow{2}{*}{ years } & \multirow{2}{*}{$\begin{array}{c}\text { Area of } \\
\text { section }(\mathrm{m} 2)\end{array}$} & \multicolumn{2}{|c|}{ Reduction of area compared with1981 } & Percentage of the \\
\cline { 3 - 5 } & Absolute value $\left(\mathrm{m}^{2}\right)$ & Relative value (\%) & \\
\hline 1981 & 2573 & & & 54.8 \\
\hline 1988 & 1409 & -1164 & -45.2 & 43.8 \\
\hline 1996 & 1128 & -1445 & -56.2 & 37.4 \\
\hline 2000 & 962 & -1611 & -62.6 & 32.2 \\
\hline 2003 & 829 & -1744 & -67.8 & \\
\hline
\end{tabular}

(3) Toudaoguai section

As is shown in Figure 9, the flow shape and cross section area of Toudaoguai section change over time. It is found that the flow shape has changed remarkably with time, while the flow area is reduced less compared with the reduction in other sections. Besides, the flow shape was quite regular in 1981, which was changed into more regular shape with the erosion of sand drift and deposition of silt in deep trough. Based on a water stage of $989.9 \mathrm{~m}$, the variation of cross section area in different periods since 1981 is shown in Table 3.

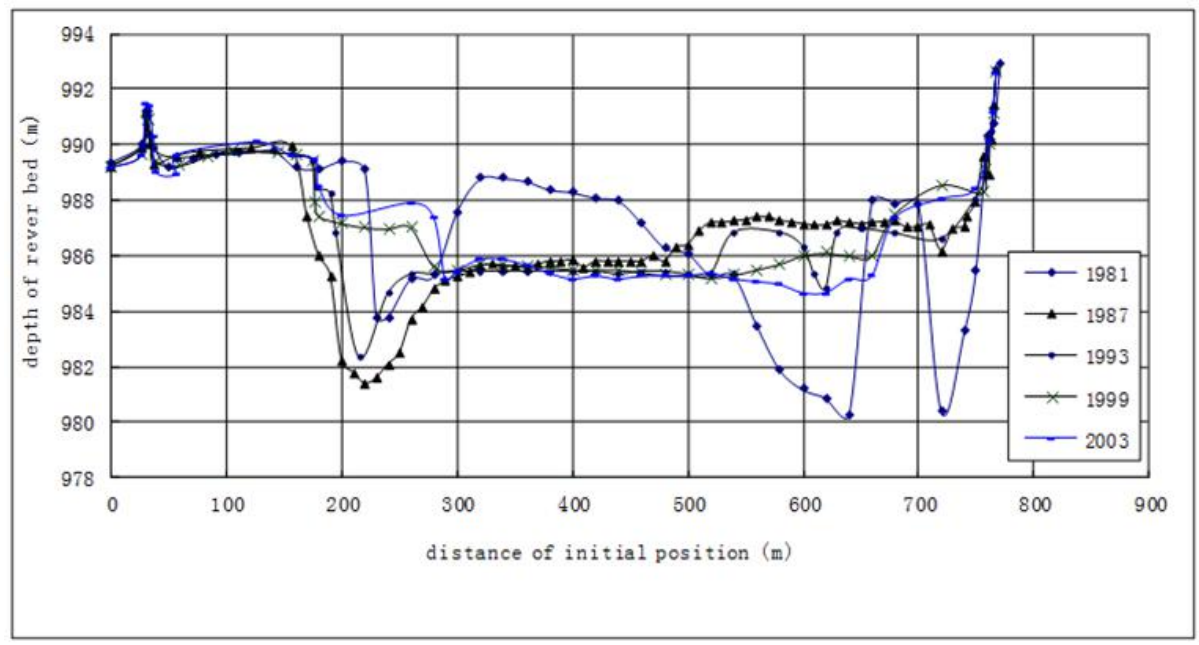

Fig. 9. Graph of cross section of Toudaoguai in past years

Table 3. The situation of reduction for the area of different periods of Toudaoguai

\begin{tabular}{|c|c|c|c|c|}
\hline \multirow{2}{*}{ years } & \multirow{2}{*}{$\begin{array}{c}\text { Area of } \\
\text { section } \\
\end{array}$} & $\begin{array}{c}|c| \\
(\mathrm{m} 2)\end{array}$ & Reduction of area compared with1981 & $\begin{array}{c}\text { Percentage of } \\
\text { the area of } 1981 \\
(\%)\end{array}$ \\
\hline 1981 & 2309 & & & \\
\hline 1987 & 2375 & +66 & +2.9 & 1.029 \\
\hline 1993 & 2340 & +31 & +1.3 & 1.013 \\
\hline 1999 & 2140 & -169 & -7.3 & 92.7 \\
\hline 2003 & 2185 & -124 & -5.4 & 94.6 \\
\hline
\end{tabular}




\section{Reduction of water-carrying capacity in each section}

\subsection{Alteration on rating curves with time}

(1) Bayangaole section

The rating curve variation of Bayangaole section in unimpeded period has been figured out and shown in Figure 10. As is shown, the line shape and trend are similar each year with a largest discharging volume in 1981. Besides, the discharging volume has been diminishing since then due to constant deposition of the river bed.

Based on the rating curve in 1981, the rating curve of other years with a water stage of $1052.0 \mathrm{~m}$ can be deducted and drawn in accordance with the trend. Please refer Table 4 for a comparison of various water discharge rates over the years with that in 1981 at the same water stage over the years (Shi, 2016).

As is shown in Table 4, ever since 1981, the water-carrying capacity has been decreasing year by year. When the discharge rate is above $5000 \mathrm{~m}^{3} / \mathrm{s}$, the water stage will reach no less than $1054 \mathrm{~m}$ based on rating curve of 2003 i.e. the water stage will be approximately $2 \mathrm{~m}$ higher than the peak water stage in the large flood of September 1981.

(2) Sanhuhekou section

The rating curve variation of Sanhuhekou section in unimpeded period has been figured out and shown in Figure 11. As is shown, the line shape and trend are similar each year, which are like those from 1981 to 1996 . However, the curve of 2003 becomes steep. Generally speaking, the discharge rate at the same water stage is diminishing year by year, for the riverbed has been silting up constantly.

Based on the rating curve in 1981, the rating curve of other years with a water stage of $1020.0 \mathrm{~m}$ can be deducted and drawn in accordance with the trend. Please refer Table 5 for a comparison of various water discharge rates over the years with that in 1981 at the same water stage over years.

As is shown in Table 5, water-carrying capacity has been decreasing year by year since 1981. If the discharge rate is above $5000 \mathrm{~m}^{3} / \mathrm{s}$ in the future, the stage will reach no less than $1022 \mathrm{~m}$ based on the trend of the rating curve in 2003, which means the water stage is approximately $2 \mathrm{~m}$ higher than the peak water stage in the large flood of September 1981.

(3) Toudaoguai section

The rating curve variation of Toudaoguai section in unimpeded period has been figured out and shown in Figure 12. It is found that the line shape and trend of relations are similar each year, even the rating curve of each year is different. Based on the rating curve in 1981, the rating curve of other years with a length of $990.3 \mathrm{~m}$ can be deducted and drawn in accordance with the trend. Please refer Table 6 for a comparison of various water discharge rates with that in 1981 at the same water stage.

As is shown from Table 6, ever since 1993, the water discharge rates at all water stage levels have been smaller than that in 1981. If the discharge rate is above $5000 \mathrm{~m}^{3} / \mathrm{s}$ in the future, the water stage will reach no less than $990.4 \mathrm{~m}$ based on the rating curve in 2003 , which means the water stage is approximately $2 \mathrm{~m}$ higher than the peak water stage in the large flood of September 1981 (He et al., 2009). 


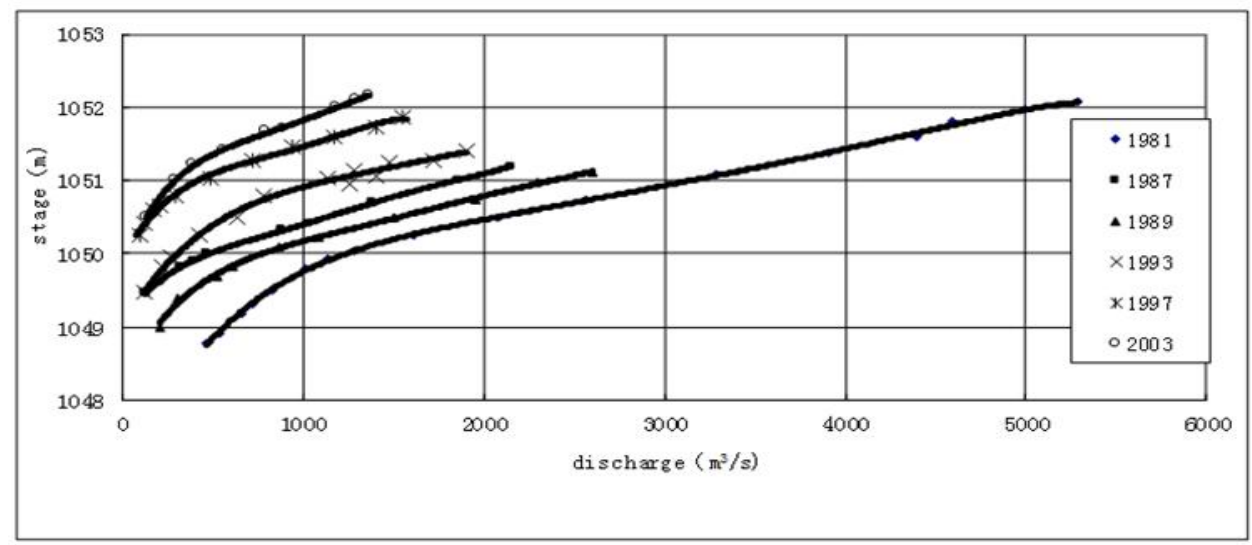

Fig. 10. Graph of rating curves of Bayangaole in past years

Table 4 Statistic table for discharge at all levels stage in free weir period over the years in ayangaole and the proportion of 1981

\begin{tabular}{|c|c|c|c|c|c|c|c|c|}
\hline \multirow{3}{*}{ years } & \multicolumn{70}{|c|}{ Level of stage } \\
\cline { 2 - 9 } & $\begin{array}{c}\text { Discharge } \\
\text { from line } \\
\left(\mathrm{m}^{3} / \mathrm{s}\right)\end{array}$ & $\begin{array}{c}\text { Percentage } \\
\text { of } 1981 \\
(\%)\end{array}$ & $\begin{array}{c}\text { Discharge } \\
\text { from line } \\
\left(\mathrm{m}^{3} / \mathrm{s}\right)\end{array}$ & $\begin{array}{c}\text { Percentage } \\
\text { of 1981 } \\
(\%)\end{array}$ & $\begin{array}{c}\text { Discharge } \\
\text { from line } \\
\left(\mathrm{m}^{3} / \mathrm{s}\right)\end{array}$ & $\begin{array}{c}\text { Percentage } \\
\text { of 1981 } \\
(\%)\end{array}$ & $\begin{array}{c}\text { Discharge } \\
\text { from line } \\
\left(\mathrm{m}^{3} / \mathrm{s}\right)\end{array}$ & $\begin{array}{c}\text { Percentage } \\
\text { of } 1981 \\
(\%)\end{array}$ \\
\hline 1981 & 2080 & & 3150 & & 4120 & & 5100 & \\
\hline 1987 & 1130 & 54.3 & 1850 & 58.7 & 2700 & 65.5 & 3590 & 70.4 \\
\hline 1989 & 1520 & 73.1 & 2390 & 75.9 & 3280 & 79.6 & 4240 & 83.1 \\
\hline 1993 & 580 & 27.9 & 1120 & 35.6 & 2090 & 50.7 & 3140 & 61.6 \\
\hline 1997 & 150 & 7.2 & 410 & 13.0 & 1040 & 25.2 & 1820 & 35.7 \\
\hline 2003 & 140 & 6.7 & 290 & 9.2 & 630 & 15.3 & 1200 & 23.5 \\
\hline
\end{tabular}

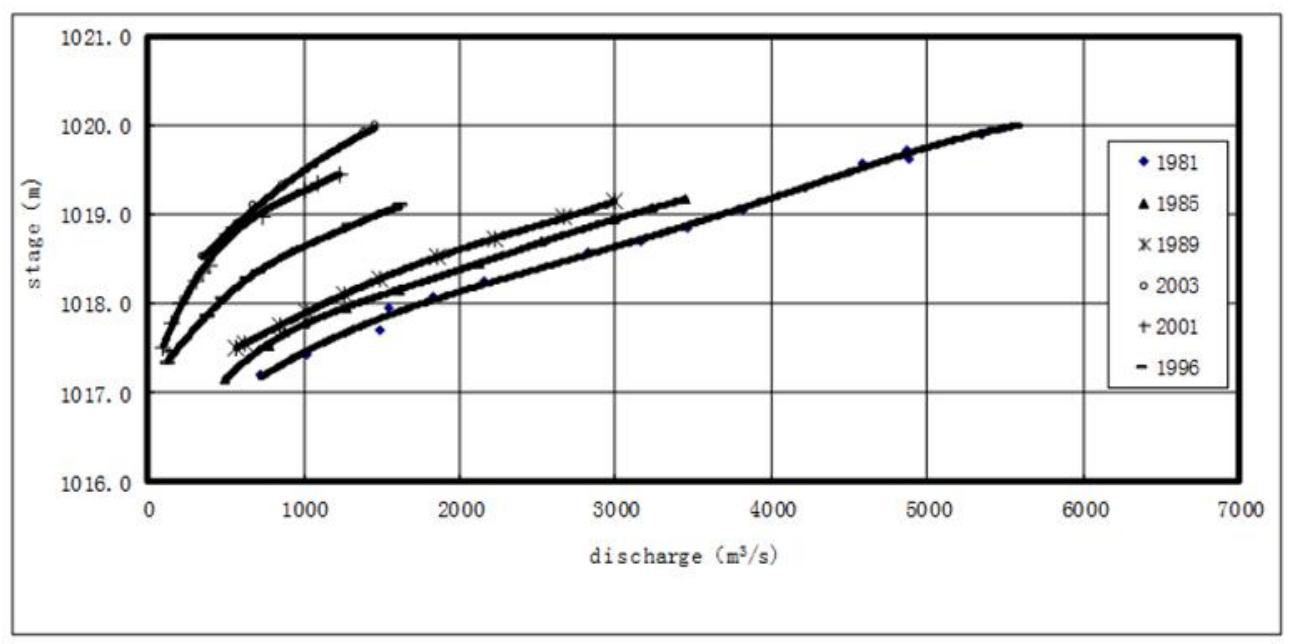

Fig. 11. Graph of rating curves of Sanhuhekou in past years 
Table 5. Statistic table for discharge at all levels stage in free weir period over the years in

Sanhuhekou and the proportion of 1981

\begin{tabular}{|c|c|c|c|c|c|c|c|c|}
\hline \multirow{3}{*}{ years } & \multicolumn{70}{|c|}{ Level of stage } \\
\cline { 2 - 9 } & $\begin{array}{c}\text { Discharge } \\
\text { from line } \\
\left(\mathrm{m}^{3} / \mathrm{s}\right)\end{array}$ & $\begin{array}{c}\text { Percentage } \\
\text { of } 1981 \\
(\%)\end{array}$ & $\begin{array}{c}\text { Discharge } \\
\text { from line } \\
\left(\mathrm{m}^{3} / \mathrm{s}\right)\end{array}$ & $\begin{array}{c}\text { Percentage } \\
\text { of } 1981 \\
(\%)\end{array}$ & $\begin{array}{c}\text { Discharge } \\
\text { from line } \\
\left(\mathrm{m}^{3} / \mathrm{s}\right)\end{array}$ & $\begin{array}{c}\text { Percentage } \\
\text { of } 1981 \\
(\%)\end{array}$ & $\begin{array}{c}\text { Discharge } \\
\text { from line } \\
\left(\mathrm{m}^{3} / \mathrm{s}\right)\end{array}$ & $\begin{array}{c}\text { Percentage } \\
\text { of } 1981 \\
(\%)\end{array}$ \\
\hline 1981 & 2740 & & 3680 & & 4550 & & 5570 & \\
\hline 1985 & 2200 & 80.3 & 3110 & 84.5 & 4050 & 89.0 & 5000 & 89.8 \\
\hline 1989 & 1840 & 67.2 & 2730 & 74.2 & 3660 & 80.4 & 4650 & 83.5 \\
\hline 1996 & 850 & 31.0 & 1480 & 40.2 & 2300 & 50.5 & 3140 & 56.4 \\
\hline 2001 & 400 & 14.6 & 730 & 19.8 & 1320 & 29.0 & 2140 & 38.4 \\
\hline 2003 & 380 & 13.9 & 650 & 17.7 & 1000 & 22.0 & 1480 & 26.6 \\
\hline
\end{tabular}

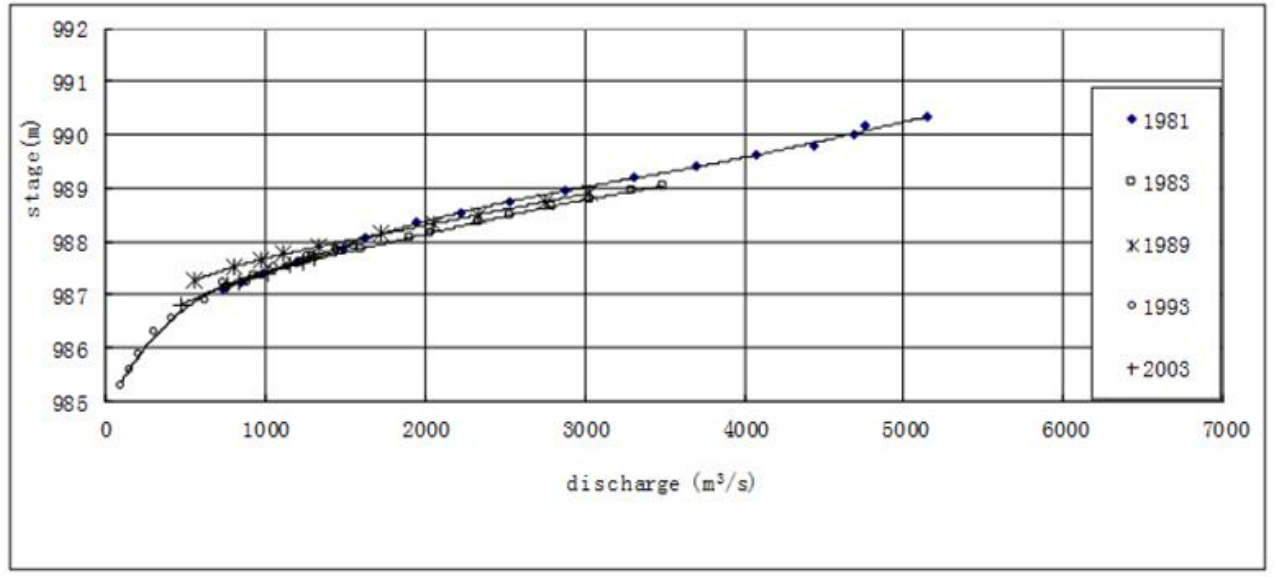

Fig. 12. Graph of rating curves of Sanhuhekou in past years

Table 6. Statistic table for discharge at all levels stage in free weir period over the years in Toudaoguai and the proportion of 1981

\begin{tabular}{|c|c|c|c|c|c|c|c|c|}
\hline \multirow[b]{3}{*}{ years } & \multicolumn{8}{|c|}{ Level of stage } \\
\hline & \multicolumn{2}{|c|}{$988.0 \mathrm{~m}$} & \multicolumn{2}{|c|}{$989.0 \mathrm{~m}$} & \multicolumn{2}{|c|}{$990.0 \mathrm{~m}$} & \multicolumn{2}{|c|}{$990.3 \mathrm{~m}$} \\
\hline & $\begin{array}{l}\text { Discharge } \\
\text { from line } \\
\left(\mathrm{m}^{3} / \mathrm{s}\right)\end{array}$ & $\begin{array}{c}\text { Percentage } \\
\text { of } 1981 \\
(\%)\end{array}$ & $\begin{array}{l}\text { Discharge } \\
\text { from line } \\
\left(\mathrm{m}^{3} / \mathrm{s}\right)\end{array}$ & $\begin{array}{c}\text { Percentage } \\
\text { of } 1981 \\
(\%)\end{array}$ & $\begin{array}{l}\text { Discharge } \\
\text { from line } \\
\left(\mathrm{m}^{3} / \mathrm{s}\right)\end{array}$ & $\begin{array}{c}\text { Percentage } \\
\text { of } 1981 \\
(\%)\end{array}$ & $\begin{array}{l}\text { Discharge } \\
\text { from line } \\
\left(\mathrm{m}^{3} / \mathrm{s}\right)\end{array}$ & $\begin{array}{l}\text { Percentage } \\
\text { of } 1981(\%)\end{array}$ \\
\hline 1981 & 1800 & & 3120 & & 4630 & & 5100 & \\
\hline 1983 & 1800 & 100 & 3430 & 109.9 & 5170 & 111.7 & 5700 & 111.8 \\
\hline 1989 & 1500 & 83.3 & 3160 & 101.3 & 4930 & 106.5 & 5500 & 107.8 \\
\hline 1993 & 1650 & 91.7 & 2750 & 88.1 & 4220 & 91.1 & 4740 & 92.9 \\
\hline 2003 & 1620 & 90.0 & 2800 & 89.7 & 4300 & 92.9 & 4830 & 94.7 \\
\hline
\end{tabular}

\subsection{Alteration of rating curves in drift periods}

The rating curves of Bayangaole, Sanhuhekou and Toudaoguai sections in stable drift period of 1982, 1988, 1998 and 2003 have been drawn to analyze their alteration over years.

(1) Rating curves of Bayangaole section 
The rating curves in stable drift period of Bayangaole section over years have been shown in Figure 13. As is shown, the line shape and trend are generally similar in curves of different years; however, the water discharge rate at the same water stage has been reducing year by year. Please refer Table 7 for the reduction value. Besides, the water-carrying capacity is also decreasing. For example, when the water stage is $1052.0 \mathrm{~m}$, the watercarrying capacity of 2003 was only $26.6 \%$ of that in 1982 . Besides, when the water discharge rate is $500 \mathrm{~m}^{3} / \mathrm{s}$, the corresponding water stage in 2003 is approximately $2 \mathrm{~m}$ higher than that in 1982.

(2) Rating curves of Sanhuhekou section

The rating curves in stable drift period of Sanhuhekou section over years have been shown in Figure 14. As is shown, the line shape and trend of curves in different periods are quite different. Generally speaking, the water discharge rate at the same water stage has been reducing year by year (see Table 8). Besides, the water-carrying capacity is also decreasing. For example, when the water stage is $1020.0 \mathrm{~m}$, the water-carrying capacity of 2003 was only $25.0 \%$ of that in 1982 . From another perspective, when the water discharge rate is $500 \mathrm{~m}^{3} / \mathrm{s}$, the corresponding water stage in 2003 is approximately $1.8 \mathrm{~m}$ higher than that in 1982.

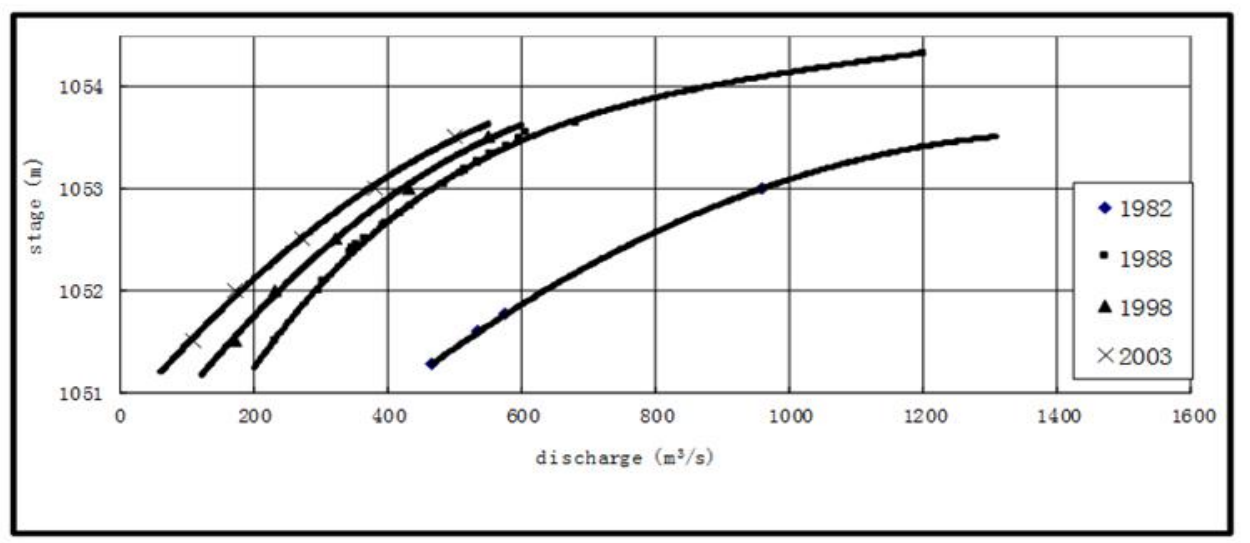

Fig. 13. Graph of rating curves in ice age of Bayangaole in past years

Table 7. Statistic table for discharge at all levels stage in ice age over the years in Bayangaole and the proportion of 1982

\begin{tabular}{|c|c|c|c|c|c|c|c|c|c|c|}
\hline \multirow[b]{3}{*}{ years } & \multicolumn{10}{|c|}{ Level of stage $(\mathrm{m})$} \\
\hline & \multicolumn{2}{|c|}{1051.5} & \multicolumn{2}{|c|}{1052.0} & \multicolumn{2}{|c|}{1052.5} & \multicolumn{2}{|c|}{1053.0} & \multicolumn{2}{|c|}{1053.5} \\
\hline & $\begin{array}{l}\text { Dischar } \\
\text { ge from } \\
\text { line } \\
\left(\mathrm{m}^{3} / \mathrm{s}\right)\end{array}$ & \begin{tabular}{|c} 
Percenta \\
ge of \\
1982 \\
$(\%)$
\end{tabular} & $\begin{array}{l}\text { Dischar } \\
\text { ge from } \\
\text { line } \\
\left(\mathrm{m}^{3} / \mathrm{s}\right)\end{array}$ & \begin{tabular}{|c} 
Percenta \\
ge of \\
1982 \\
$(\%)$
\end{tabular} & $\begin{array}{c}\text { Discharg } \\
\text { e from } \\
\text { line } \\
\left(\mathrm{m}^{3} / \mathrm{s}\right)\end{array}$ & $\begin{array}{c}\text { Percenta } \\
\text { ge of } \\
1982 \\
(\%)\end{array}$ & $\begin{array}{l}\text { Discharg } \\
\text { e from } \\
\text { line } \\
\left(\mathrm{m}^{3} / \mathrm{s}\right)\end{array}$ & $\begin{array}{c}\text { Percenta } \\
\text { ge of } \\
1982 \\
(\%)\end{array}$ & $\begin{array}{l}\text { Discharg } \\
\text { e from } \\
\text { line } \\
\left(\mathrm{m}^{3} / \mathrm{s}\right)\end{array}$ & \begin{tabular}{|c|} 
Percenta \\
ge of \\
1982 \\
$(\%)$ \\
\end{tabular} \\
\hline 1982 & 520 & & 640 & & 780 & & 970 & & 1250 & \\
\hline 1988 & 230 & 44.2 & 290 & 45.3 & 370 & 47.4 & 470 & 48.5 & 610 & 48.8 \\
\hline 1998 & 170 & 32.7 & 230 & 35.9 & 320 & 41.0 & 430 & 44.3 & 555 & 44.4 \\
\hline 2003 & 110 & 21.2 & 170 & 26.6 & 270 & 34.6 & 380 & 39.2 & 500 & 40.0 \\
\hline
\end{tabular}




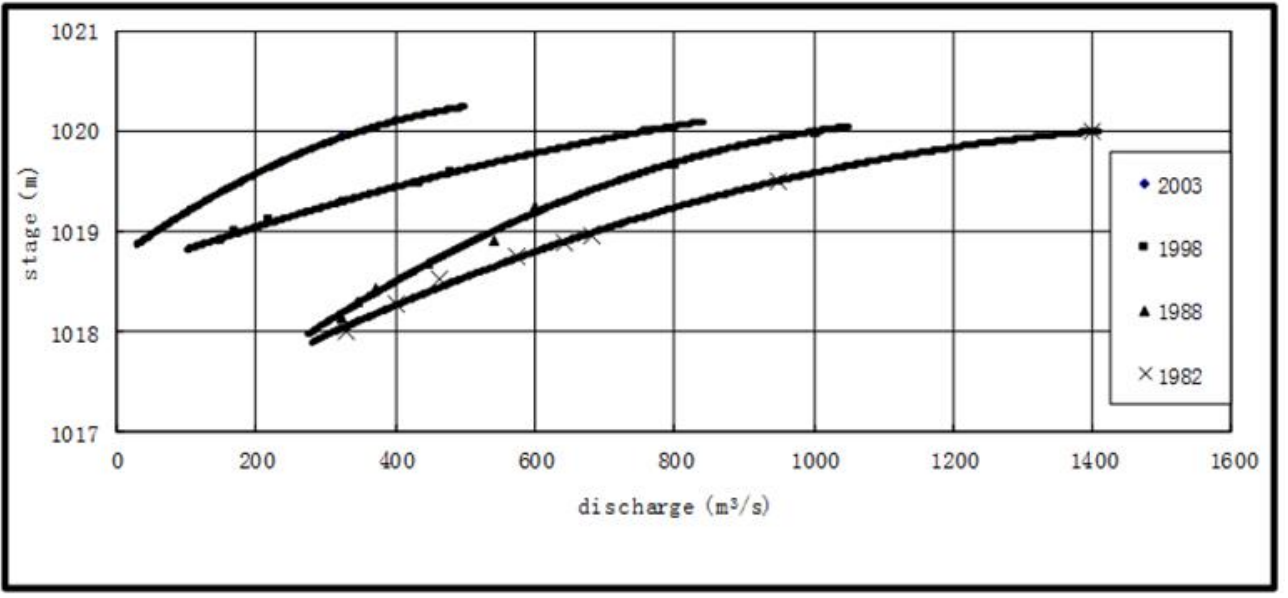

Fig.14. Graph of rating curves in ice age of Sanhuhekou in past years

Table 8. Statistic table for discharge at all levels stage in ice age over the years in Sanhuhekou and the proportion of 1982

\begin{tabular}{|c|c|c|c|c|c|c|}
\hline \multirow[b]{3}{*}{ years } & \multicolumn{6}{|c|}{ Level of stage $(\mathrm{m})$} \\
\hline & \multicolumn{2}{|c|}{1019.0} & \multicolumn{2}{|c|}{1019.5} & \multicolumn{2}{|c|}{1020.0} \\
\hline & $\begin{array}{l}\text { Discharge } \\
\text { from line } \\
\left(\mathrm{m}^{3} / \mathrm{s}\right)\end{array}$ & $\begin{array}{c}\text { Percentage of } \\
1982(\%)\end{array}$ & $\begin{array}{c}\text { Discharge } \\
\text { from line } \\
\left(\mathrm{m}^{3} / \mathrm{s}\right)\end{array}$ & $\begin{array}{l}\text { Percentage of } \\
1982(\%)\end{array}$ & $\begin{array}{l}\text { Discharge } \\
\text { from line } \\
\left(\mathrm{m}^{3} / \mathrm{s}\right)\end{array}$ & $\begin{array}{l}\text { Percentage of } \\
1982(\%)\end{array}$ \\
\hline 1982 & 695 & & 950 & & 1400 & \\
\hline 1988 & 540 & 77.7 & 720 & 75.8 & 1010 & 72.1 \\
\hline 1998 & 180 & 25.9 & 435 & 45.8 & 770 & 55.0 \\
\hline 2003 & 60 & 8.6 & 180 & 18.9 & 350 & 25.0 \\
\hline
\end{tabular}

(3) Rating curves of Toudaoguai section

The rating curves in stable drift period of Toudaoguai section over years have been shown in Figure 15. As is shown, the rating curve of 1982 is steeper than those of the other three years, mainly because two sand pile drifts with a height of $3.3 \mathrm{~m}$ and $2.7 \mathrm{~m}$ were silted up in 1982, leading to more sluggish flow in the section afterwards. For the other three years, since the sand pile drifts disappeared, the curves are well-regulated. Generally speaking, the overall water discharge rate at the same water stage has been reducing year by year (see Table 9). Besides, the water-carrying capacity is also decreasing over years. For example, when the water stage is $988.0 \mathrm{~m}$, the water-carrying capacity of 2003 is only $68.9 \%$ of that in 1982. From another perspective, when the water discharge rate is $400 \mathrm{~m}^{3} / \mathrm{s}$, the corresponding water stage in 2003 is approximately $0.6 \mathrm{~m}$ higher than that in 1988 .

It is necessary to point out here that the rating curve of Toudaoguai section in free flow period of 2003 is lower than those of the other three years. Besides, most rating curves in drift period of this section from 1998 to 2003 are low. After analysis, it is deducted that the construction of Wanjiazhai reservoir operated in 1998 is one of the reasons. 


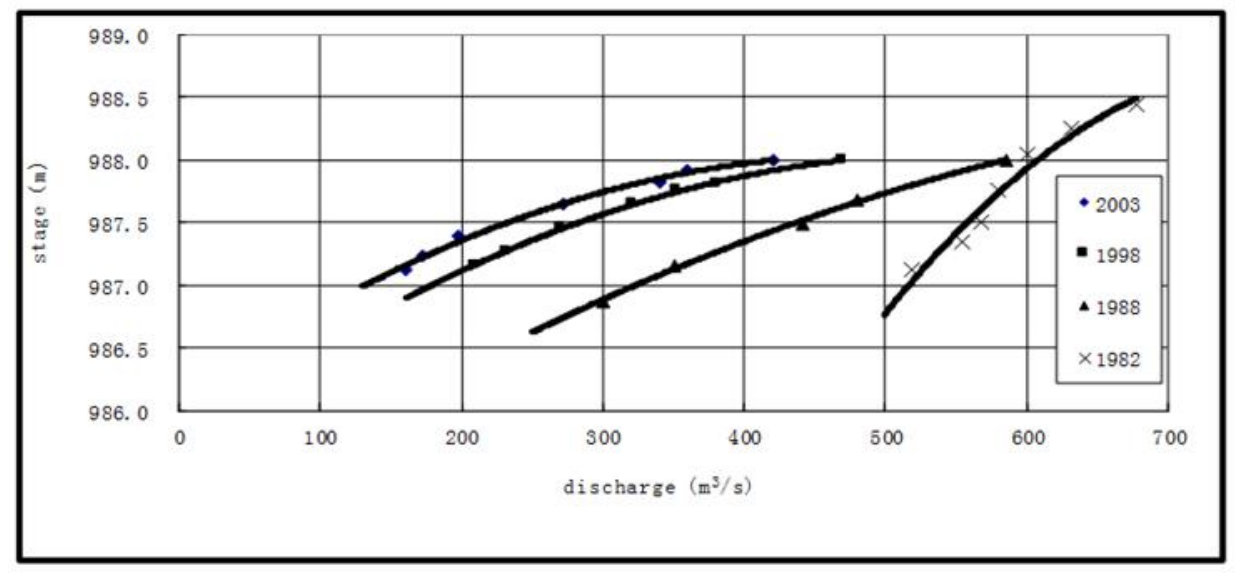

Fig. 15. Graph of rating curves in ice age of Toudaoguai in past years

Table 9. Statistic table for discharge at all levels stage in ice age over the years in Toudaoguai and the proportion of 1982

\begin{tabular}{|c|c|c|c|c|c|c|}
\hline \multirow{3}{*}{ years } & \multicolumn{6}{|c|}{ Level of stage $(\mathrm{m})$} \\
\cline { 2 - 7 } & \multicolumn{2}{|c|}{987.0} & \multicolumn{2}{c|}{987.5} & \multicolumn{2}{c|}{988.0} \\
\cline { 2 - 7 } & $\begin{array}{c}\text { Discharge } \\
\text { from line } \\
\left(\mathrm{m}^{3} / \mathrm{s}\right)\end{array}$ & $\begin{array}{c}\text { Percentage of } \\
1982(\%)\end{array}$ & $\begin{array}{c}\text { Discharge } \\
\text { from line } \\
\left(\mathrm{m}^{3} / \mathrm{s}\right)\end{array}$ & $\begin{array}{c}\text { Percentage of } \\
1982(\%)\end{array}$ & $\begin{array}{c}\text { Discharge } \\
\text { from line } \\
\left(\mathrm{m}^{3} / \mathrm{s}\right)\end{array}$ & $\begin{array}{c}\text { Percentage of } \\
1982(\%)\end{array}$ \\
\hline 1982 & 515 & & 560 & & 610 & \\
\hline 1988 & 325 & 63.1 & 435 & 77.7 & 585 & 95.9 \\
\hline 1998 & 185 & 35.9 & 280 & 50.0 & 470 & 77.0 \\
\hline 2003 & 135 & 26.2 & 230 & 41.1 & 420 & 68.9 \\
\hline
\end{tabular}

\section{Variation of bankfull discharge rate in varied periods}

According to flood documentation, the bankfull discharge rate of the Yellow River Inner Mongolia section in 1981 was $4400 \mathrm{~m}^{3} / \mathrm{s}$ to $5100 \mathrm{~m}^{3} / \mathrm{s}$; when the discharge rate was 3000 $\mathrm{m}^{3} / \mathrm{s}$, the riverbed began to be seriously eroded. However, with the deposition over years, the overbank discharge rate of the section from Bayangaole to Sanhuhekou has been reduced to $1500 \mathrm{~m}^{3} / \mathrm{s}$, and when the discharge rate reaches $3000 \mathrm{~m}^{3} / \mathrm{s}$, the overbank will be quite severe. Please refer Table 10 below for overbank discharge rate in various periods.

Table 10. Overbank discharge of each station at varied periods

\begin{tabular}{|c|c|c|c|c|c|}
\hline \multirow{2}{*}{ stations } & \multirow{2}{*}{\begin{tabular}{c} 
overbank \\
stage \\
\cline { 3 - 6 }
\end{tabular}} & \multicolumn{4}{|c|}{ overbank discharge $\left(\mathrm{m}^{3} / \mathrm{s}\right)$} \\
\cline { 3 - 6 } & 1052.0 & 5100 & 1989 & 1996 & 2003 \\
\hline Bayangaole & 10900 & 2000 & 1200 \\
\hline Sanhuhekou & 1019.8 & 5100 & 4200 & 2800 & 1300 \\
\hline Toudaoguai & 989.8 & 4400 & 4500 & 4200 & 4000 \\
\hline
\end{tabular}

\section{Reference}

1. W.H. Chang, S.Z. Hou, X.C. Li, P. Wang, Yellow River, 31, 5, 38-39. (2009)

2. S.D. He, Y.F. Wang, G.Y. Duan, Hydrology, 4, 40-43. (2009)

3. S.Z. Hou, W.H. Chang, J Sediment Res , 3, 44-50. (2010) 
4. S.Z. Hou, P. Wang, W.H. Chang, W.B. Chu, Yellow River, 29, 4, 21-22. (2007)

5. X.M. Li, Y.P. Lin, Y.S. Li, L. Wang, Yellow River, 31, 8, 23-24. (2009)

6. X.Y. Liu, S.Z. Hou, W.H. Chang, J Hydraul Eng, 9, 1048-1054. (2009)

7. C.X. Shi , Scientia Geographica Sinica, 36, 6, 895-901. (2016)

8. H.B. Shen, B.S. Wu, S. Zheng, W.W. Li, Adv Water Resour , 24, 4, 477-482. (2013)

9. T. Su, S.J. Wang, Y.G. Mei , Acta Geographica Sinica, 70, 3, 488-500. (2015)

10. T. Su, S.J. Wang, Y.G. MEI, W.W. Shao, J Geogr Sci , 25, 8, 930-942. (2015)

11. H. Tang, X.Z. Lin, T. Hu, L.S. Su, Yellow River, 37, 7, 5-8. (2015)

12. B.S. Wu, K.J. Liu, H.B. Shen, L.Y. Zhou, Adv Water Resour , 26, 3, 311-321. (2015)

13. B.S. Wu, Y.Q. Wang, Y.J. Wang, L.Y. Zhou, J Sediment Res, 3, 8-14. (2015)

14. S.J. Wang, X.L. Fan, Progress in Geography, 4, 501-506. (2010)

15. G.S. Yang, W.Q. Tuo, F.N. Dai, Y.X. Liu, K. Jing, B.Y. Li, O.Y. Zhang, R. Lv, L.F. $\mathrm{Hu}, \mathrm{Y}$. Tou , Journal of Desert Research, 23, 2, 152-159. (2003) 